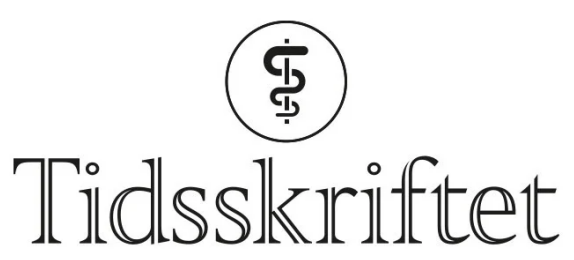

DEN NORSKE LEGEFORENING

\title{
Kristian Hannestad
}

\author{
MINNEORD
}

TROND JØRGENSEN

BJØRN SKOGEN

KRISTIAN BARTNES

ANNE HUSEBEKK

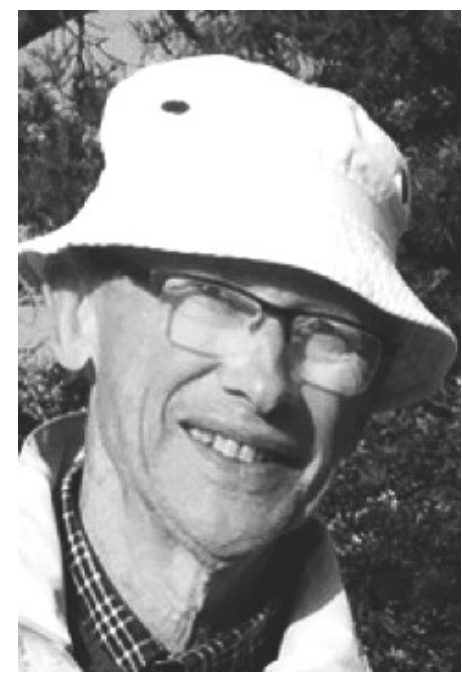

Kristian Hannestad døde 16.8.2021, 88 år gammel. Han var i 1973 en av de første professorene som ble tilsatt ved Universitetet i Troms $\emptyset$, og var med på å starte medisinutdanningen i Tromsø. Han var også med på oppbyggingen av avdelingen for immunologi og transfusjonsmedisin ved Universitetssykehuset Nord-Norge og var avdelingsoverlege i perioden 1973-90.

Vi er mange som har hatt glede av Kristian Hannestads store innsikt i immunologi. Han husket alt han leste og sluttet aldri å søke ny kunnskap i et fagfelt som utviklet seg raskt. Kristian kom til Tromsø fra det immunologiske forskningsmiljøet på Rikshospitalet, og da han dro fra Tromsø i 2000, var det for å være professor emeritus i immunologi ved Universitetet i Oslo. Immunologi opptok ham helt til sykdom satte en stopper for det faglige arbeidet. 
Kristian var en krevende veileder og merittert underviser. Han var ikke så opptatt av at alle forsto eller skulle interessere seg for immunologi, men for dem som viste interesse, var han utrettelig i sin iver etter å gi kunnskap og innsikt i faget. Han hadde mange ideer og en fabelaktig forskningsinnsikt og gav seg ikke før en hypotese var verifisert eller måtte forkastes. Dette kunne bety både lange arbeidsdager og krevende diskusjoner. Kristian $\emptyset$ nsket å publisere i de aller beste tidsskriftene, og det kunne være utfordrende å være stipendiat eller medarbeider. Som forsker hadde han et stort internasjonalt nettverk og var på forskningsopphold ved de beste immunologiske forskningsmiljøene i verden.

Flere av Kristians stipendiater og medarbeidere er ledende immunologer i Norge i dag og har bidratt ikke bare til kunnskap om basale immunologiske mekanismer, men også til vaksineutvikling innenfor flere områder.

Vi er dypt takknemlige for at Kristian motiverte og inspirerte oss i et fagfelt som betyr så mye innen moderne medisin.

Våre tanker går til Kay og hans to sønner. Vi lyser fred over Kristian Hannestads minne.

Publisert: 11. oktober 2021. Tidsskr Nor Legeforen. DOI: 10.4045/tidsskr.21.06o6

(C) Tidsskrift for Den norske legeforening 2023. Lastet ned fra tidsskriftet.no 26. april 2023. 